\title{
Reaction from Women in Poor Families to Poverty Alleviation Programs in the Province of Bali, Indonesia
}

\author{
Ida Ayu Nyoman Saskara, I Wayan Yogi Swara, \\ I Gusti Bagus Indrajaya, I Gusti Putu Nata Wirawan, I Wayan Wita Kesumajaya \\ Lecture from Faculty of Economic and Business of Udayana Univeristy, Indonesia
}

\begin{abstract}
This study aims to evaluate the response of women in poor rural families to poverty alleviation programs in the province of Bali. It is also to identify weaknesses or problems in the implementation of poverty alleviation in the province of Bali. This research was conducted in all districts / cities in the province of Bali, with a total sample of 25 respondents in each district / city, bringing the total respondents as many as 225 women in poor families throughout Bali. Samples were determined by purposive sampling of informants needed, and using accidental sampling for the poor respondents. Methods for collecting data is using structured interviews and in depth interviews for primary data and secondary data collected through observation. Data analysis technique is using descriptive analysis. The results showed that 98 percent of respondents who received help poverty alleviation program stated that the aid benefit to their lives. Some of the weaknesses or the constraints identified in the implementation of rural poverty reduction programs include budget constraints, social and political factors, as well as the quality of human resources.
\end{abstract}

Keywords: Women, poverty alleviation, governemtn assistance, rural

\section{Introduction}

Development programs launched by the Government has been giving great attention to poverty alleviation efforts. However, poverty is still a serious problem, so overcome requires the right strategy and sustainable. The number of poor people in Bali in 2011 as many as 183.1 thousand people and nearly 50 percent are in rural areas. Even in 2010, the number of poor people in rural areas is higher than in urban areas, although there is a decrease in the number of poor from 2010 to 2011 (Central Bureau of Statistic, 2011). Livelihood of Indonesian people especially Bali who live in rural areas as farmers is that a large part of the population classified as poor. Considering half of Indonesia's population is female, the increased empowerment of women are expected to contribute to the poverty alleviation program. Poverty remains a problem to be alleviated for the realization of the ideals of the founding of the Republic of Indonesia, namely social justice for all Indonesian people. The development program launched by the government has been giving priority to reducing poverty, but until now, poverty is still a problem so we need appropriate strategies to mitigate them. Poverty in the village depends on two things: First, the development program in the village itself specifically; Second, the program development district as a whole. Each county has a regional development program (Propeda) and from there drafted a strategic plan (Renstra) which is an annual. In general, the village does not have its own development program, which is carried out during this time was the development of villages by district development program and not according to the rural development program. Under Law Number 22 Year 1999 Junto Act No. 34 of 2004 Junto Act No. 3 of 2005 on Regional Autonomy, the village has been given the authority to plan the construction of the village, but in fact they have not been able to carry out the task. Human Resources (HR) owned the village is still very limited both in quality and quantity, so far most of the villages do not have a definite program to address the poverty that has occurred in the village. Likewise, the problem of gender disparity between men and women in development has not occurred by the decision-makers in the village.

Many sectors of development should be realized, one of them is the development in the field of women's empowerment, the assessment of the problem has many dimensions. The problems that must be followed is the one position to play a role in development, namely rural development, more of whom are poor women who have not empowered corresponding potential .As for potential Balinese village are agriculture and tourism. Saskara, at all (2012) reported that women Bali working public sector to contribute to the family income, thus indirectly help poverty alleviation program. Likewise delivered Chandrakirana (2000), that women are better prepared to cope with the economic difficulties of households, especially in times of crisis.

Poverty must be eradicated for the realization of a just and prosperous society in accordance with the ideals of the founding of the Republic of Indonesia. Related to the sustainability of poverty reduction programs, it is important to know the response of the recipient (in this case women in poor families) to poverty alleviation programs. In addition, it is also important to identify weaknesses or problems in the implementation of poverty eradication programs to be drawn up measures for the improvement of poverty alleviation programs in the province of Bali. 


\section{Definition of Poverty}

\section{Literature review}

United Nations Development Programme (UNDP) defines poverty as hunger, lack of shelter, the inability of seeing a doctor when sick, do not have access to school and are illiterate, do not have a job, fear for the future, living in a daily basis, inability to obtain clean water, powerlessness, and a lack of representation and freedom. Meanwhile, according to Government Regulation No. 42 In 1981, the poor are the people who did not have a source of livelihood and does not have the ability to meet basic needs eligible for humanity or people who have a livelihood but can not meet basic needs befitting human beings.

Despite the poor is not a new reality in society, but to date the definition of poverty is still problematic because it is so complicated in some sense the measurement variable. There are no standard definition that is mutually acceptable by experts about poverty. By paying attention to the definitions of theoretical noted above, the operational definition of poverty that is expressed here is the condition of a person or group of people who can not make ends meet the minimum required to be able to live a decent and develop a dignified life in accordance with basic rights they.

According to the BAPPENAS (2004), the basic rights of the poor is contained in the Strategic Plan (Plan) several areas in Indonesia include: (1) the right to obtain decent work for humanity; (2) the right to obtain legal protection; (3) the right to acquire a sense of security; (4) the right to have access to the necessities of life (food, clothing, board) affordable; (5) the right to have access to educational needs; (6) the right to have access to health; (7) the right to obtain justice; (8) the right to participate in public decision-making and governance; (9) the right to innovate, as well as (1) the right to participate in organizing and managing good governance.

People who are least able to meet the basic rights of those considered poor, while those not able to fulfill it can be categorized as poor. Despite the fact, in order to live a decent different for each individual depending on age, residence, and others. Poverty also has a form of the compound, including low levels of income and productive resources that ensures sustainable livelihoods, hunger and malnutrition, poor health, limitations and lack of access to education and other basic, the condition is not fair, as well as deaths from the disease continue increased life vagrancy and inadequate shelter, unsafe environment, as well as discrimination and social alienation. Poverty is also characterized by a low level of participation in the decision-making process as well as in life, social, and cultural.

\section{Causes of Poverty}

Nasikun (2001) highlights some of the sources and causes of poverty, namely:

1. Induces Policy Processes. Process poverty preserved, reproduced through the implementation of a policy (induced of policy) include anti-poverty policies, but the reality is precisely to preserve.

2. Socio Economic dualism. Namely the state of former colonies experienced poverty since the colonial patterns of production, namely the farmers become marginal for arable land controlled by large scale farmers and export-oriented.

3. Population Growth. Perspective is based on the theory of Malthus that population increases geometrically as, being the increase of food such as arithmetically.

4. Resources Management and the Environment. The existence of an element of mismanagement of natural resources and the environment, such as the management of agricultural origin slash and can reduce productivity.

5. Natural Cycles and Processes. Namely poverty occurs due to natural cycles. Suppose living on degraded land, where the land is if it rains flooding will occur, but if the dry season water shortage, thus not allowing the maximum productivity and continuously.

6. The Marginalitation of Woman. Is the marginalization of women because it is still regarded as second-class so that access to and appreciation is lower than men.

7. Culture and Ethnic Factor. Operation of cultural and ethnic factors exist maintain poverty. For example consumptive lifestyles, the farmers and fishermen when the harvest, and customs during traditional ceremonies that can suck the cost prohibitive.

8. Exploitative intermediation. The existence of a helper who became mugger, such as moneylenders.

9. Internal Political Fragmentation and Civil Stratfe. That is a policy that is applied to an area of strong political fragmentation, and can be a cause of poverty. And the last is:

10. International Processes. Namely the operation of the international systems such as colonialism and capitalism that made many countries to be poor.

In the view of poverty in general, if viewed from a contributing factor, it is distinguished by: cultural poverty, natural and structural. Cultural poverty is poverty caused by cultural factors, such as: lazy, undisciplined, wasteful and so forth. Natural Poverty is poverty caused by natural factors such as: for disabled, sick, elderly, and because of natural disasters. While structural poverty is poverty caused by man-made factors, such as: the distribution of productive assets unequal, unjust economic policies, corruption and collusion, as 
well as the economic order which tends to favor a particular group. The theory is based on sosioantropologis see poverty as a result of cultural factors that emphasized the cultural influences that tend to perpetuate poverty. While based economy saw poverty as a result of natural factors such as the low quality of human resources and natural resources, and structural factors such as inequality of ownership of factors of production, low capital formation community and the low incentive to investment.

\section{Basic Policy on Poverty Alleviation}

Government has a major role in tackling poverty in the country. For that we need a strategy and appropriate form of intervention, in terms of its high cost effectiveness. There are three main pillars of the poverty reduction strategy, which is as follows:

1. Sustainable economic growth and poverty pro.

2. Good governance, as well as

3. Social development

To support the strategy, required government interventions suited to the goals or objectives (Tambunan, 2006). Prayitno and Santosa (1996), poverty reduction measures always need to consider several things, among others:

1. Poverty reduction programs and effective work only if there is a peaceful and stable atmosphere. The stability is absolutely necessary to ensure the continuity of the implementation of poverty reduction programs because basically poverty reduction efforts is an attempt to create peace and political stability, economic, social and political.

2. Village poverty programs can be effective if the population growth can be controlled. Prosperous small family is one of the factors conducive to achieving the objective tackling poverty.

3. Poverty reduction programs should be linked to the environment. Environment remain stable and properly maintained allowing distribution of wealth between citizens equally.

4. Poverty reduction programs must be a sustainable program, a program that can be constantly running and can be independent. This means that poverty alleviation programs should be based on improving the ability of the poor to productive activities that can generate higher added value and a greater income from an activity. Efforts to improve the ability to produce value-added at least there should be improved access to four things:

a. Access to resources.

b. Access to technology, which is an activity in the manner and means of better and more efficient.

c. Access to the market. The resulting product must be sold to obtain added value. This means that the provision of the means of production and upgrading of skills must be matched with the availability of market continuously.

d. Access to financing sources.

5. Delegation of authority or decentralization in planning, implementation, and monitoring of poverty reduction programs were pursued at the lowest possible level of government. Delegation of authority is done by increasing the ability of local officials and the community itself. In this connection, local governments should take a greater role because they are the most knowledgeable about the condition and needs of the population in poverty in the region kantongkantong. The closer implementing projects and activities with the target group, the more effective.

6. The most important pressure should be given to the improvement of the culprit, especially human (invest in people) concerning aspects of education and health. Both are associated with increased access evenly and at the same time better quality.

7. Services for the elderly, the disabled, orphans, and other community groups that require an integral part of the effort to reduce poverty. This program is specifically and selectively implemented. A necessary step is to improve the effectiveness, efficiency, and outreach programs. In keeping with the development of the social security system needs to be improved gradually.

\section{Research Location}

\section{Research Method}

This study will be conducted in all districts / cities in Bali which can be classified as rural by the potential of agriculture and tourism industries. The district has a village with a dominant agricultural potential is Tabanan, Buleleng, Bangli and Jembrana. Meanwhile Denpasar, Badung, Gianyar, Klungkung and Karangasem has a dominant village with tourism potential.

\section{Number of Samples and Sampling Methods}

The number of samples examined in all districts / municipalities in the province of Bali as many as 225 respondents (women belonging to poor families) were spread evenly across districts / cities are respectively 25 respondents. Samples were taken with method non-probability sampling is accidental sampling, in accordance with criteria that are important to those who are classified as poor (Pre Family Welfare and Family Welfare I). Sampling for the informant is by purposive sampling.

DOI: $10.9790 / 5933-0803016776 \quad$ www.iosrjournals.org $\quad 69 \mid$ Page




\section{Type, Data Source, and Data Collecting}

Types of data collected is quantitative and qualitative data derived from primary and secondary data. For the first year of primary data collected from respondents by using instruments interviews and in-depth interviews for other sources. Secondary data from the institutions or agencies associated with the literature study, or observation.

Measured variables include the characteristics of respondents crate age, type of work, amount of revenue, and time allocation of poor women who work in the public sector in rural areas, the contribution of Balinese women who work in the public sector to the family income. Data required in this study were collected through interviews based on the questionnaire that has been prepared for the respondents, and in-depth interview, the informant as from government officials involved in the handling of the poor.

\section{Data Analysis}

The data collected will be analyzed descriptively based on the value of descriptive statistics were obtained. Descriptive statistics were used, among others, frequency distribution, average value, median or mode of the data collected. It is also used cross tabulation analysis between the variables required.

\section{Data Analysis And Discussion Characteristics of Respondents/Poor People in Rural Areas of Bali Province Age of Respondents}

Age is one variable of many variables called demographic variables, and includes one of the characteristics of the respondent. Age of respondents is closely related to productivity that can be achieved, the general relationship of productivity which in this case can be represented by the respondent's income is affected by age. Distribution of respondents by age as in Figure 1.

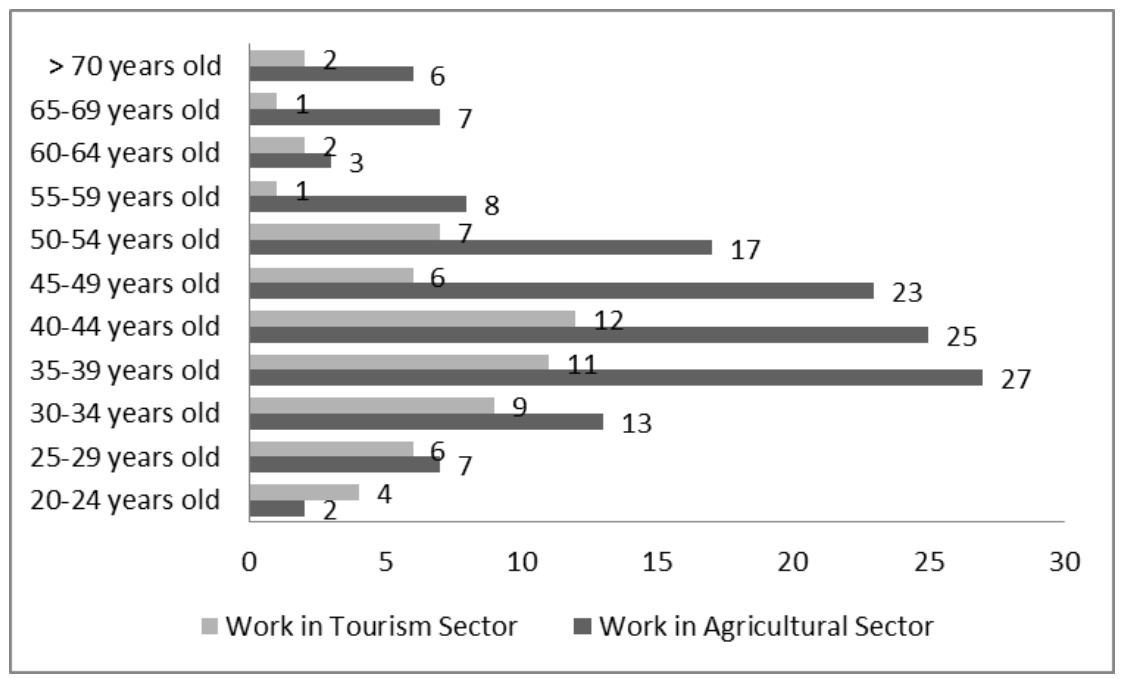

Figure 1. Distribution of Respondents by Age Group and Sector

Figure 1 shows that in general the respondents are normally distributed. The percentage of respondents increased with increasing age of the respondent and peaked at age 40-44 years. After the age group, the percentage of respondents continue to decline. From these data it is also seen that more than 90 percent of respondents were in the productive age, only about 7 percent were classified as not economically productive, although they are still working to earn income. So the pattern of distribution of respondents by age group in total inverted U-shaped is following a pattern common.

When viewed by region with agriculture and tourism potential and age, Table 1 also shows that in absolute terms in the age group 40-44 years both the number of respondents who work in agriculture and tourism, at least compared with other age groups. By percentage of respondents in the agricultural sector is the highest distributed in the age group 15-19 years, and the lowest is in the age group 60-64 years. The opposite is true of those working in the tourism Distributed highest in the age group 60-64 years, and the lowest are in the age group 15-19 years. From the patterns according to age groups both in agriculture and in the tourism sector is not seen no clear pattern in the distribution of respondents. There is a possibility because of the number of respondents who distributed by age group if it is divided into the sectors of agriculture and tourism are relatively few in number, so it does not follow a normal distribution. 


\section{District Origin of Respondent}

Among the respondents, only a small portion coming from districts / cities outside your district / city of residence of the respondent. The majority of respondents came from the district / city in which they live. Of the total respondents only about 20 percent of the respondents who live outside the district / city their home. If used as a district or city boundaries migrant concept, it can be said the respondents in the study only about 20 percent of the status of migrants, while the remaining approximately include 80 percent of non-migrant. Data also showed that the respondents were classified as migrant to stay in residence now (when the study was conducted) the shortest 2 years and a maximum of about 43 years.

\section{Marital Status and Number of Children}

In terms of marital status, the majority of respondents, about 94 percent are in marital status and the remaining approximately 6 percent in the status of widow / divorced. Among all respondents only about 5 percent who do not have children, which is characterized by the data number of children is 0 . The number of children most of the respondents are as many as 7 people, and among respondents, most of the respondents who have children 2 which is about 35 percent. This means that government slogans through BKKBN that two children is better seems to be accepted by society so that the percentage of respondents who only had two children among the highest in the number of children in the category of other respondents. In addition pretty much the respondents who have children 5 or more people that is nearly 10 percent. There are some general reasons why a family to have more children than 4 people this today. The main reasons that can be said is that families do not have children with the desired gender, the family usually prefer to have their sons as successors of family obligations in a large family. This is because the family in Bali embraced patrilineal kinship system where the family lineage was based on patrilineal, so the boys in the family will generally always be expected in a family.

\section{Education Level of Respondent}

Education is one of the variables considered so important in improving the quality of the population. One of the indicators used to calculate the Human Development Index (HDI) or Human Development Index (HDI), is education in addition to two other indicators, namely health status and economic views from income. Education of respondents can be seen in Figure 2.

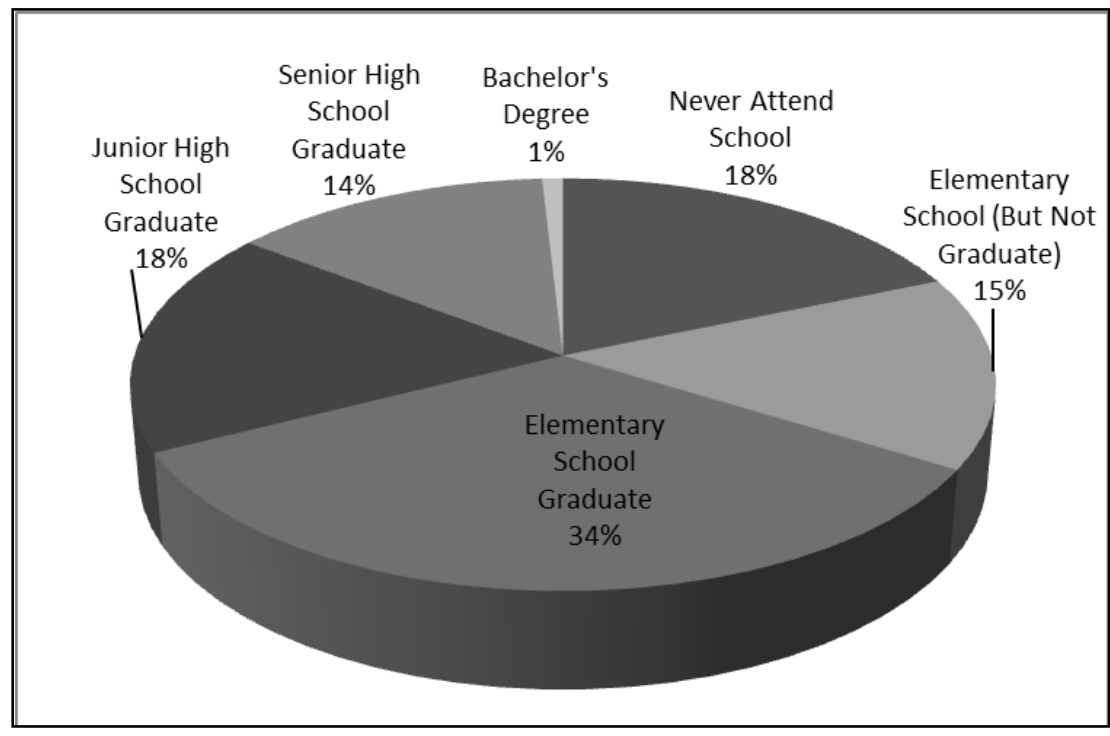

Figure 2. Distribution of Respondents by Education Level

Figure 2 shows the respondents with elementary education down 67.6 percent. So about 68 percent of respondents with low education, and even among the nearly 19 percent who never went to school, in other words they are illiterate or unable to read or write. The distribution is based on only about 32 percent of the junior high school education and above, and only less than 1 percent have higher education. From this data it can be said the respondents' education tends to be low, at only about 15 percent had high school education and above. With this kind of education conditions may also affect their income, and of course have an impact on the classification of their families as families who are poor that are in Pre Family Welfare and Family Welfare I category. Thus the government programs that aim to increase their income should be a priority in reducing the number of poor people in the province of Bali. 
In terms of the agricultural and tourism potential of the distribution of respondents according to education is not too much difference with the state of education respondents in total. Respondents were college educated (University) everything works in the agricultural sector, so that no respondents with higher education who work in the field of tourism. The study was conducted in rural areas, so it seems highly educated respondents are also working in the agricultural sector. Respondents were distributed at all levels of education if it is seen by agriculture and tourism potential of the region, except in higher education. When viewed in absolute terms in both the regional potential both in agriculture and tourism most number of respondents have completed primary school education, the same condition with the data in total. Thus both in agriculture and in tourism most of the respondents with low education so that these conditions play a major role in determining their income.

\section{Occupation and Income of Respondents}

From the data collected was not all respondents in work status, but most of their work status is about 72 percent, and the remaining approximately 28 percent in the status of not working. Thus, if they do not work then of course they will have no income. Respondents who are distributed into three sectors, namely agriculture, tourism services, and more. Among those who have the status of work as much as 64.20 per cent in the agricultural sector, respondents who work in tourism services as much as 24.69 percent, and in other sectors as much as 11.11 percent. As well as the distribution of respondents according to the potential of agriculture and tourism, the distribution of respondents according to the pattern of employment is also the same, most respondents work in the agricultural sector. Or job-specific characteristics of respondents will determine future policies or programs to increase their income so as to reduce the number and percentage of respondents who are under the poverty line. From the data of respondents who work have income that varies significantly from one another. The main income of the lowest respondents only 100,000, - per month, and as high as Rp. 1.500.000, which is solely owned by 3.1 percent of respondents. Respondents who have an income of Rp. 1.000.000, - up to Rp. 1.200 .000 , - only about 5.56 percent. So respondents who earn Rp. 1.000 .000 , - up only about 8.7 percent, and the remaining 91.3 percent had incomes of under Rp. 1.000.000, -. The average income per month primary respondent only Rp. 552110 , - and when totaled with an average additional income pengasilan they increased to Rp. 592 500, -. When compared to the Minimum Regional Wage in each district or province by more than 3 percent have income equal to or above the minimum wage. So most have incomes below the minimum regional wage, which means their income in the low category. Seeing this condition programs that fronted the government had to be done in order to increase their income. Income is also one of the variables used to calculate the Human Development Index (HDI) in addition to education and health. The increase in earnings of society in general and specifically the study respondents would definitely be able to improve the HDI residents of the district / city, which can indicate the success of the construction carried out. It is also a mirror increase public welfare as the goal of national development.

The respondent's income can also be seen by region with agriculture and tourism potentials in all districts / cities. Income respondents in both regions may also be a reflection of the level of welfare of respondents in each region. In Figure 3 the respondent's income submitted by the potential of the agriculture and tourism. Figure 3 shows that the pattern of the respondent's income in areas with agricultural potential to tourism is almost the same, just a slightly different magnitude. In both groups, earning the category into two, namely from Rp. $500-<1000$ thousand an income with the highest percentage. In both groups earning the least percentage of respondents also found in the same group, namely the income of Rp. 1 million and above. Therefore, those in the group are classified as Pre Family Welfare and Family Welfare I category, although those in regions with different potential income turns out they are not much different.

In the study also asked respondents whether their relevant income is sufficient for their livelihood. This question is considered very important to know the level of their welfare indirectly. The results showed that the majority of respondents, about 93.8 per cent stated that their income is insufficient to meet their basic needs. The rest is only about 6.2 percent stated that their income is sufficient. This condition is understandable given that they belong to the category of the population in Pre Family Welfare and Family Welfare I category, so most likely the income they get from work is not sufficient to meet their basic needs. In a family or household in general, not only husbands who work to earn a living, but also wives, and children. In poor families, in general, all family members participate in contributing to the family income. In other words they will go in the labor market to help the family economy. In this study also looks like it, from the existing data wife's income is not sufficient to finance all the needs of family life, the other family members will be involved as a husband and children. Data collected from respondents largely aided by their husbands to fund the rest of their income. This makes sense and is understandable because until now the husband is seen as the main breadwinners in a family, so of course the husband who must take responsibility for the family's needs. From the data that there are about 85 percent of the respondents stated that the revenue shortfall will be helped or financed by their husbands, only a small part assisted by the child or by another family. 


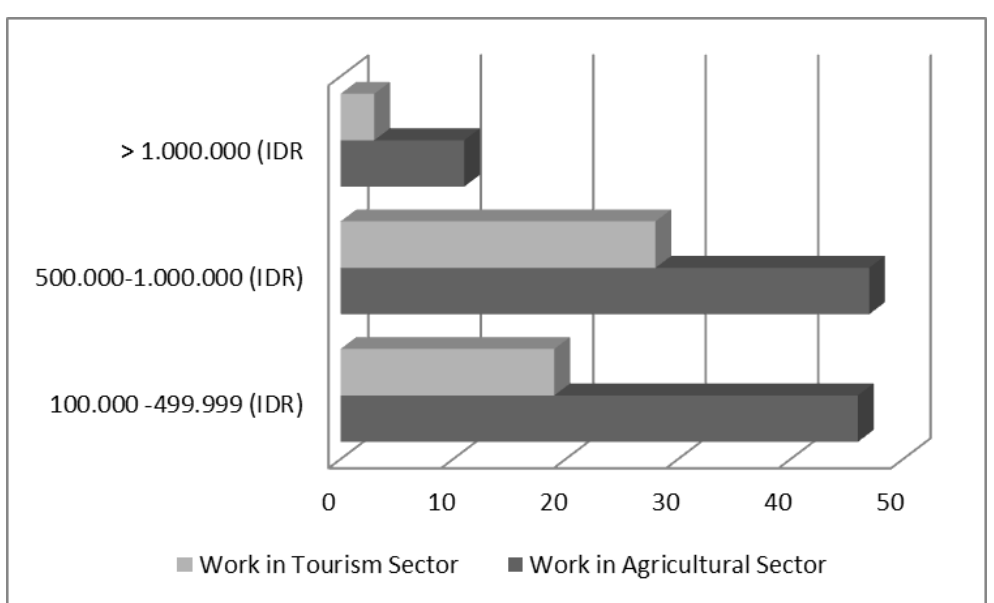

Figure 3. Distribution of Income of Respondents by Region With Potential of Agriculture and Tourism

Based on the data obtained from the Central Bureau of Statistics (2012), the poverty line in Bali province has increased from year to year. Until the year 2012 the edge of poverty per capita per month in Bali Rp. 249 997, -, this means that if a family has a child as much as 3 people, with a father and mother to a total of 5 people, then at least in the family income must be earned around Rp. 1,500,000, - per month. If a family with a number of children 3, family income is below Rp. 1.500 .000 , - then the family classified as being below the poverty line. If the observed distribution of respondents by income, it was the mode of the respondent's income is Rp. 500.000, - and if it is connected with the Minimum Regional Wage in the Province of Bali which has been approached about Rp. 1.000.000, -, then of course the majority of respondents were earning below the minimum wage. This condition also reflects that the average income of respondents in the lower state. So from the data that there are about 91 per cent of respondents had incomes of under Rp. 1.000.000, -. Thus roughly speaking around 91 percent of respondents had incomes below the minimum wage, and this also reflects that the economic conditions of the respondents is relatively low. The state of the respondent as should be the reference for businesses or programs / policies in order to increase their income.

\section{Average Working Hours of Respondents}

If seen from hours worked, average hours worked respondents is approximately 6.6 hours per day. Of this average, the shortest working hours is 4 hours per day, and the maximum 12 hours per day. The percentage of respondents who have working hours per day 9 hours to the top is very low at only about 2.5 percent of the total respondents were working. Based on the collected data were also obtained information that most respondents work within a period of 8 hours per day which is a mode of respondents working hours per day. The percentage of respondents with working hours of 8 hours per day is about 40 per cent of the total respondents were working. Working hours per day that ranks second is 6 hours owned by about 22 per cent of the respondents worked. On the average, the respondents working hours per day is 6.6 hours. This means that if used deadline normal working hours per day is 8 hours, it can be said the average hours of work respondents remained below normal working hours. Or it can be said to occur underemployment in terms of working hours experienced by respondents in this study. It also implicitly reflect if there is a government program that aims to supplement their income by increasing their old work, then of course it can still be carried out considering the hours they work are still relatively low or below normal working hours.

Besides work, the respondents also use the time to housework or domestic chores. From the available data the average time the respondent to do any housework or domestic about 4.4 hours per day, with hours of domestic work the least 2 hours per day and a maximum of 12 hours. If seen an average ratio of domestic work hours by an average of public business hours or hours of work a living turned out to respondents in this case women in households classified as poor have an average income of working hours to 6.6 hours per day is much longer than the average working hours for domestic work / household only 4.4 hours per day. Similarly, if you compare the lowest working hours or pattern is the same condition that most low income working hours is 4 hours, while the working hours for domestic work most low of just 2 hours. This gives an indication of the poor households in time to work a living to be so important to earn income to support family needs. Another indication that can be learned or inferred from the results of this study based on the data the average hours of work income and working hours for domestic work are the respondents / women have experienced a change in allocating time you have that much more to work a living than to work domestically, in women who have the status of work. In another sense though women work a living, they still have to take domestic jobs with an average time is also relatively long every day. 
In the family in general, especially in families who belong Pre Family Welfare and Family Welfare I category, in addition to the wife (housewife), the husband must also find work a living to provide for their families. Based on research data of the total respondents that there are about 87.1 percent of the respondents in the husband's work status, and the remaining less than 13 percent in the status of not working. Understanding this can not work in the sense they do not work and looking for work, and also did not find a job because the conditions are not possible. From the data that there are about 28 per cent of respondents husband who does not work, when the study was conducted was trying to find job, and the rest more are not looking for work.

If the comparison between the two data is the percentage of working husbands around 87 percent and the percentage of wives / respondent who works about 72 percent. These data also reflects until now the husband can still be said to be the economic backbone of the family, because there are families whose wife or in this case the respondent did not work, so the husband who are all accountable for household expenses. However, most households is 72 percent financed by at least one of the two sources, the husband and wife / respondents. This means that the respondents also gave significant contribution to the welfare of their families. Husband of respondents who have the status of work, about 48 percent work in agriculture, 25 percent in the field of tourism, and the remaining 27 percent in other sectors. If compared between husband and wife employment / respondents, the relative difference is in agriculture and other sectors. Respondents / wife works in the agricultural sector around 64 percent while 48 percent of husbands working in the sector, while in other sectors around 11 percent of the respondents / wife works in this sector, while 27 percent husband absorbed in other sectors. Almost the same percentage of the husband and wife / respondents working in the field of tourism which is about 25 percent. Thus it can be seen that the husband has a more varied occupations than the wife / respondents.

\section{Income of Respondents's Husband}

To see how the role of the respondent / wife in the household economy can be seen from the average income of a family member. Based on the research results obtained by the husband's income tends to be higher than the income of the respondent / wife. It can be seen from the lowest income derived respondent husband is Rp. 100,000 - the same condition that the lowest income the wife / respondents. On the other hand the highest amount of the husband's income is Rp. 4.200.000, - which is solely owned by one person, while the respondent / wife has the highest income is only Rp. 1.500 .000 , -. Also in terms of earnings mode, the mode wife's income / respondents were also lower than her husband's income mode is the mode husband's income 600.000, - owned by about 14 per cent of respondents husband, and the second largest order is earning Rp. 1.000.000, - owned by about 13 per cent of respondents. On the other hand mode respondent's income / wife is significantly lower at Rp. 500.000, - owned by about 21 per cent of respondents, and the second is the income of Rp. 300.000, - the percentage of respondents about 19.5 percent. With that in mind, we can conclude that wife's income / respondents tend to be lower than the income earned by their husbands. If made in the form of frequency distribution husband percentage of respondents by income group can be seen in Figure 4 .

Based on the data in Figure 4 and Figure 3 were compared with data on income distribution respondent / wife can be seen that there is a difference in the percentage of each group, both for agriculture and tourism. At the bottom income group for the agricultural sector, the husband of respondents only distributed about 10.9 percent while respondents / wife is much higher at over 44 percent.

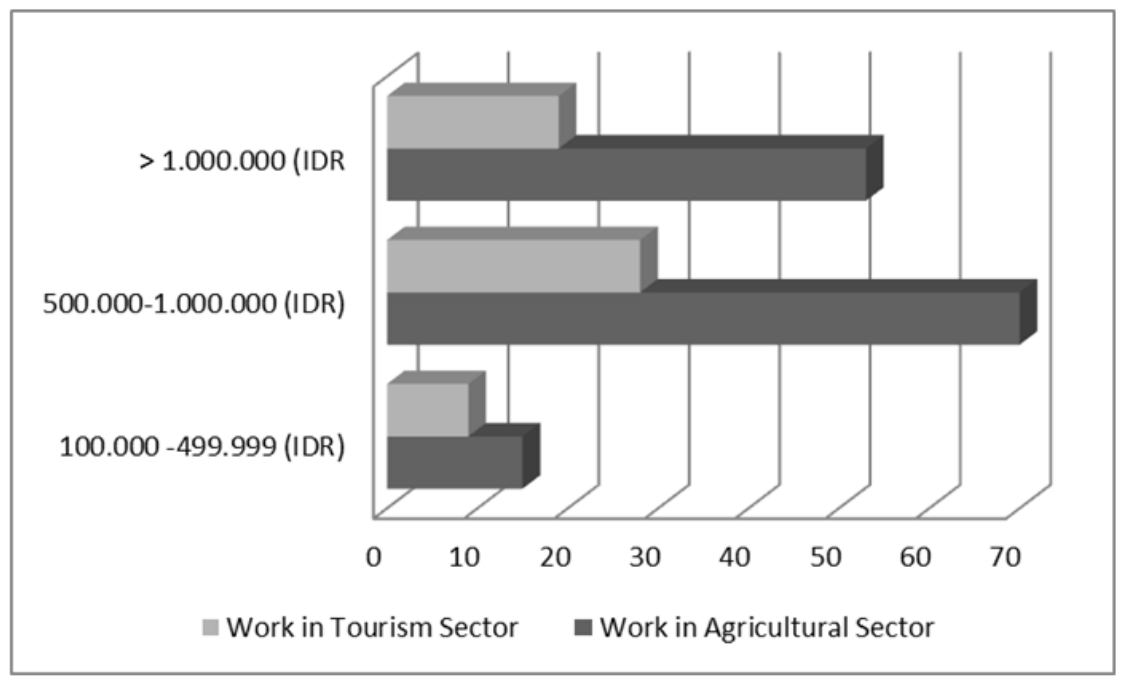

Figure 4. Distribution of Income Husband Respondents by Sector Jobs 
On the other hand in the highest income group going instead for the same sector that is about more than 38 percent of respondents husband is distributed in the highest income group, while the wife / respondents distributed to the group only about 10.6 percent. Even for the middle income group also a higher percentage than the husband with the wife on the group. The same condition also occurs in the husband's income distribution as well as respondents who work in the field of tourism. In the group of lowest income husband respondents distributed about 16 percent, while the wife / respondents distributed around 38 percent, whereas in the group earning the highest, respondents only distributed about 6 percent, but the husband of respondents even reach 34 percent of that income in that group. By looking at these conditions, it can be concluded the respondent's income / wife is lower than the income earned their husbands.

\section{Poverty Alleviation Program by Government}

Poverty alleviation programs implemented by the government during aims to improve the welfare of the population. Basically means used is to reduce costs and increase the income of the poor are concerned. So there are 2 big part of poverty alleviation programs are programs aimed at reducing the expenditure of the poor by taking over the costs / expenses such by other parties such as the government or the public, and programs aimed at increasing the income of the poor, such as programs that help them to expand employment opportunities. The programs are aimed at reducing the expenditure of the poor, among others surgical, Rice for poor family, food assistance, scholarships poor, such as $J K B M$ health assistance, free medical treatment. The programs aimed at boosting employment or productive activities may include assistance of calves (veal and pork), giving boats, venture capital assistance, relief work equipment, and employment.

Based on data collected over 90 percent had heard about the poverty program that aims to improve the welfare of the poor. Besides of total respondents that there are about 81 percent as many as 182 respondents have received assistance from the government's poverty alleviation program. Of the respondents who had received the support of about 98 per cent stated that the aid they received to provide benefits to their lives. The types of assistance they received is presented in Figure 5. below.

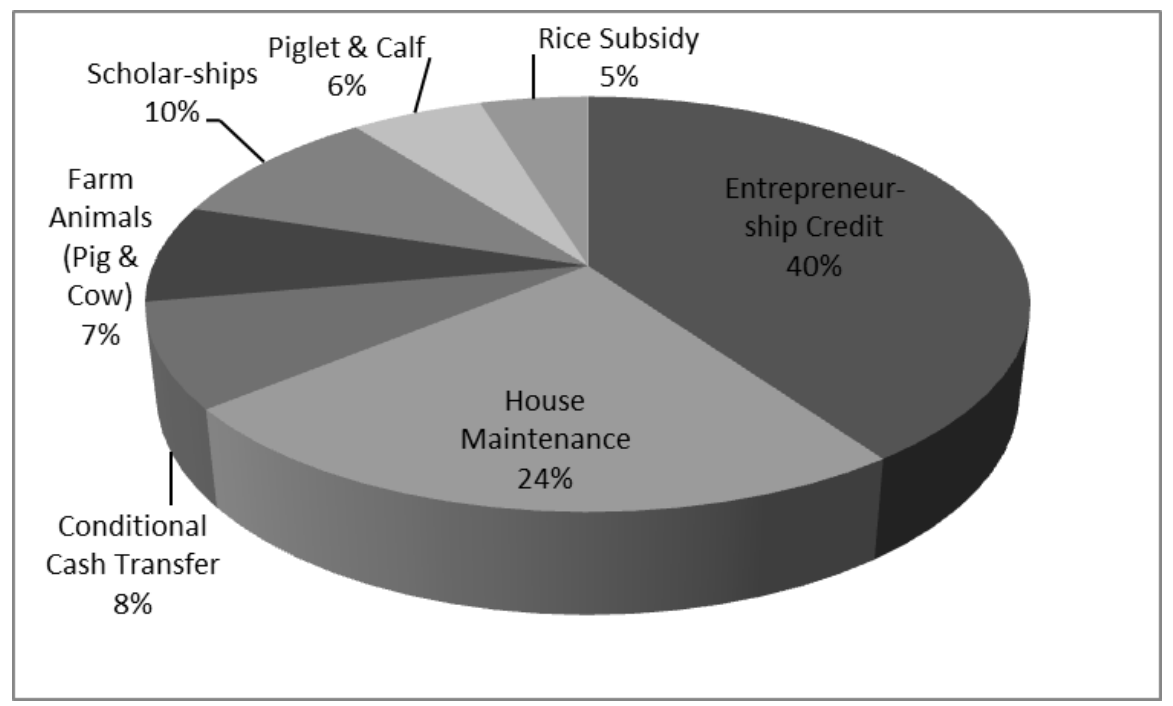

Figure 5. Distribution of Respondents According to the Poverty Alleviation They Ever Received

Of the total respondents who had received the assistance that is 182 people, about 98 percent felt that the aid they have received is very beneficial for families, and only about 2 percent of total respondents saying the help is not helpful. When asked further whether the aid they receive is sufficient or not, it turns out the majority of which is about 66 percent said the help they get is not sufficient for their day-to-day, and only about 34 percent feel the assistance they received was sufficient. When respondents were asked if they wanted help again in the future if there is aid, it turns out almost all the respondents, 98 percent said they would help again.

\section{Conclusion and implication}

Various poverty alleviation programs have been conducted by the government. Programs that are most widely accepted by the respondent is a Venture Capital Assistance Program, which was followed by surgical programs, educational expenses, cash assistance, help cattle and pigs, pigs seed aid, and groceries. The results showed most still want help from the government again considering they feel relief they have earned so far are not enough to meet their basic needs. Some of the weaknesses or the constraints identified in the implementation of the program are: 1) understanding is not the same; 2) the quality of human resources; 3) political factors; 4) 
cultural / moral community; 5) regional autonomy; 6) the limited budget / funds available. Suggestions can be submitted on the results of this research is to design each model of empowerment of poor women in Cluster 1 and Cluster 2, which should be a priority in handling so that they can get out of the poverty trap which they have experienced.

Poverty Alleviation programs will be designed from the results of this study are very need to see urgent needs of the respondents, and a program created is a program that is not productive consumptive program. Model empowerment of poor women to be designed are in two clusters, namely cluster 1, which empowers those who previously did not have an occupation that became unemployed, and the Cluster 2, which will be designed empowerment model is intended to allow them to change from workers become entrepreneurs of MSMEs. Both models of empowerment to be designed is expected to increase their income so that in terms of economic strength they are getting.

\section{References}

[1] Central Bureau of Statistic. Indonesian Population. (Jakarta: BPS, 2011).

[2] Saskara, Ida Ayu Nyoman, Pudjiharjo, Ghozali Maskie, and Agus Suman. Review of Economic Perspectives and noneconomic Balinese Women Working in the Public Sector: The Role Conflict Studies. Application Management Journal, volume 10, No. 3, September, 2012. Malang

[3] Chandrakirana, Kemala. Challenges of Change in the society and state of the Women Side in Compass "Indonesia Century XII: Amid Global siege", 2000. Jakarta: Kompas.

[4] UNDP. The Millennium Development Goals: The status of the MDGs in Indonesia. (Jakarta: United Nations Development Programme. 2011).

[5] BAPPENAS \& Fitness Assessment and Development of People's Economy. Agroekonomika Foundation. National Movement Towards Poverty, Study Joint Development Policy. Jakarta. 2004.

[6] Nasikun. Declining Poverty in Indonesia, in the Poverty Trap, Problems and Strategies Poverty (Bagong Suyanto, ed) (Surabaya: Airlangga University Press. 1995).

[7] Tambunan, Tulus. Economic Indonasia, Theory and Empirical Findings. (Jakarta: Ghalia Indonesia, 2006)

[8] Prayitno, Hadi and Budi Santosa. Economic development. (Jakarta: Ghalia Indonesia, 1996). 